ISSN 1991- 8690

Website: http://jsci.utq.edu.iq

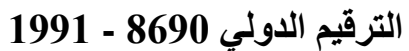

Email: utjsci@utq.edu.iq

\title{
Inhibitory Effect of Ethanolic Extract Isolated from Radix Pulasatillae Seeds against Proliferation of A549 Human Lung Cancer Cells
}

\author{
Ali A. A. Al-Shawi
}

\author{
Department Of Chemistry. College Of Education For Pure Sciences_ University Of Basrah \\ E.mail: aliabd77@yahoo.com Mobile no.: +9647702687295
}

\begin{abstract}
The present study was evaluated the anticancer activity of Radix Pulsatillae ethanol extract at first by using high throughput screening HTS for herb fractions screening in concentration of $100 \mu M$ to identify the active fraction and then we measured the cytotoxic effects by using morphology changes, and detected apoptosis by Hoechst 33258 staining. Our results showed that Radix Pulsatillae ethanol extract has a strong toxicity against A549 lung cancer cells and low toxicity with mice normal splenocytes and requires more investigation to identify the small natural molecule with new anticancer activity and further mechanistic for cancer pathways.
\end{abstract}

Keywords: Radix Pulsatillae, Lung cancer, Hoechst staining, Apoptosis, Splenocytes cells.
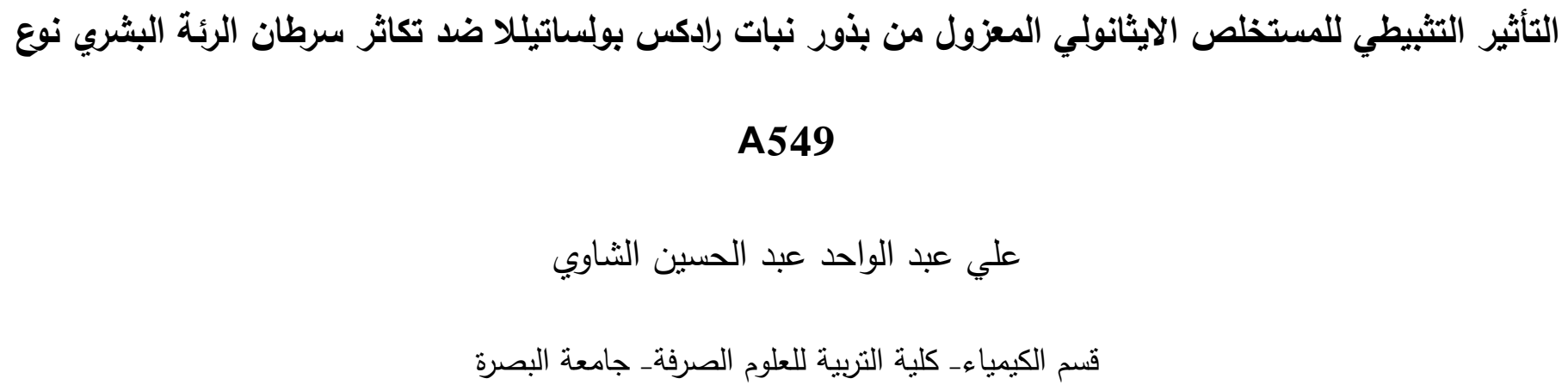

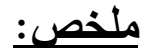

حضر المستخلص الايثانولي لنبات رادكس بولساتبلا باستخدام تقنية الحقن الانتاجي العالي الجريان. ولتحديد الفعالية السرطانية ضد خلايا سرطان الرئة

تم قياس السمية عن طريق تجربة تأثير المستخلص قبل وبعد الاضافة وبتركيز 100 مايكرومولار على تغير شكل وطبيعة الخلايا السرطانية وكذلك تجربة

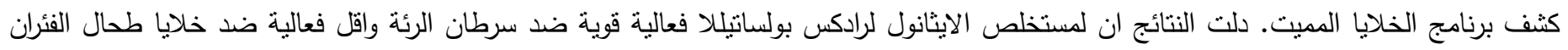

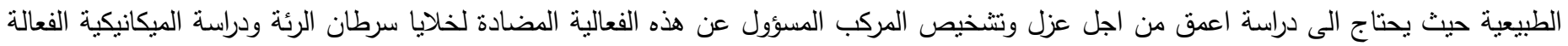

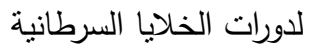

\section{Introduction}

Lung cancer is a disease starts in the lungs, in the cells lining and the lung airways and can break away and spread to other parts of the body in a process called metastasis. There are two main types of lung cancer and they are treated very differently (Small cell lung cancer (SCLC) and Non-small cell lung cancer (NSCLC)) (American Cancer Society, 
2014), and the most common cause of lung cancer is long-term exposure to tobacco which causes 8090\% of lung cancers (Horn, et.al. 2012; Rahim,et.al., 2014). The chemotherapy of lung cancer is by using two drugs (cisplatin or carboplatin) (Murray and Turrisi, 2006), Combinations with carboplatin, gemcitabine, paclitaxel, vinorelbine, topotecan, and irinotecan are used and the side effects are still main reason to destroy human body immunity, therefore ; we are looking for active anticancer drugs which treat lung cancer cells with less side effects (Azim and Ganti, 2007; MacCallum and Gillenwater, 2006). The incidence of lung cancer is 1.37 million deaths in the worldwide, and Hungary is the first top country of highest death rate (male $=36.02$ and female $=123.92$, death rate per 100,000) $($ McNabola and Gill, 2009). In 2005-2008 in Basrah provinceIraq, the incidence of lung cancer is ranked in the fifth high ratio (Total $>100$ ) of cancer risk (male $=$ 10.7 and female = 3.3) (Habib, et.al, 2010). Chinese Medicine herbs have a long history of diseases and cancer treatment and the screening of Chinese herbs will discover new herbs with new anticancer properties and identify the responsible small natural molecules for this cancer activity (Al Shawi, et.al., 2011; Khan, et.al., 2012). Chinese herbs have been used for lung cancer treatment and approximately 133 Chinese herbal medicines have been reported to possess anti-lung cancer effects such as Radix Rehmanniae, Radix Stemonae, Rhizoma Curcumae, Radix Ginseng, and Radix Adenophorae (Zhou, et.al., 2008; Guo, et.al., 2002), and some bioactive compounds isolated from Chinese medicinal herbs have been used to treat lung cancer such as Solamargine (SM) which is an alkaloid isolated from a herb, Solanum incanum, it was found to be a powerful cytotoxic agent in four human lung cancer cell lines (Liu, et.al., 2004). Radix Pulsatillae is a Chinese herb belong to Ranunculaceae family and native to East Asia, it is grown from east Siberia to Inner Mongolia, the northeast and north of China, it's bitter in flavor, cold in nature, it is related to the large intestine channel and it was used medicinally during ancient times as an external remedy for ulcers and eye inflammation, during the 19th century, European physicians noted that Pulsatillae used in the treatment of melancholy, swelling of the knees, and nervous system disorders (He, et.al. 2012; Du and $\mathrm{Hu}, 2004)$. Until now with depth literature survey, we could not find any published study shows the anticancer activity of Radix Pulsatillae against lung cancer and other cancers. In our study, we have used high throughput screening of Radix Pulsatillae ethanol extract fractions for first time to evaluate the anticancer activity against A549 small lung cancer cells by morphology changes and heochst 33258 staining to detect apoptosis effect compared with mice normal splenocytes cells.

\section{Materials and Methods}

\section{Chemical and reagents}

Fetal bovine serum (FBS have a very low level of antibodies and containing more growth factors for many vitro applications) Hangzhou Sijiqing Biological Engineering Materials Co., Ltd. DMEM culture medium, and Dimethyl sulfoxide (DMSO) were purchased from Sigma. Hoechst 5238 was purchased from Beyotime Institute of Biotechnology Jiangsu China.

\section{Preparation of Radix Pulsatillae ethanol extracts fractions}

Radix Pulsatillae herb was purchased from national institute for food and drug control and jilin xiancao medical herb limited company by the Key Research Laboratory of Cell Biology, Membrane Channels Research and Anti-Cancer Drug Discovery in the School of Life Science, Northeast Normal University, Changchun, Jilin Province China. Specimen was deposited in this Key Laboratory. Briefly, $1 \mathrm{~kg}$ of Radix Pulsatillae seeds were dried, pulverized and solubilized with 95\% ethanol for 10 hours in a soxhlet extractor at $(85-95)^{\circ} \mathrm{C}$ and more than 12 cycles to achieve maximum extraction of its ingredients. The ethanol extract was hemi-dried using rotary evaporator to get crude extract $(40 \mathrm{~g})$. To prepare ethanol extract fractions of radix pulsatillae by using HPLC preparative instrument, we dissolved the extract in $80 \%$ methanol (for HPLC preparative used) (Cannell, 1998). After centrifugation at 12000 $\mathrm{rpm}$ for 15 minutes (Centrifuge Force $=26000 \mathrm{xg}$ ), the supernatant was separated and filtered with $0.18 \mu \mathrm{m}$ filter paper (Buchner Funnel). Starting from the first peak to the end of the last peak, the extracted material was divided into 80 fractions on the basis of time (30 seconds per fraction) using HPLC. The fractions were dried and dissolved in dimethyl sulfoxide (DMSO) to obtain a $1 \mathrm{mg} / \mathrm{mL}$ stock solution. These fractions were subjected to screening for cytotoxicity against human A549 lung cancer cells; evaluate the 
cancer toxicity by using morphological changes (Rasul, et. al., 2012).

\section{Cell Culture}

Human lung cell line (A549) was purchased from the Cell Bank of Shanghai Institute of Cell Biology, Chinese Academy of Sciences (Shanghai, China). The cells were cultured in Dulbecco's Modified Eagle's Medium (DMEM) supplemented with $10 \%$ fetal bovine serum (FBS) and 100 unit of Penicillin at $37^{\circ} \mathrm{C}$ in a $\mathrm{CO} 2$ incubator with $5 \% \mathrm{CO} 2$, $95 \%$ air and $100 \%$ humidity. Cells were plated in 10 $\mathrm{cm}$ culture dish and allowed to grow to approximately $60-80 \%$ confluence before experimentation (Freshney, (2001).

\section{Analysis of toxicity on murine splenocytes}

To observe the cytotoxic effect of Radix Pulsatillae ethanol extract on normal splenocytes cells, splenocytes was isolated from CD1 (cluster of differentiation 1 is a family of glycoproteins expressed on the surface of various human antigenpresenting cells) mouse. Briefly, mouse was euthanized by overdose of pentobarbital. Spleen was surgically removed and mashed using the plunger end of the syringe in cold phosphate buffered saline. Cell suspension was centrifuged at $1500 \mathrm{~g}$ for 5 minutes and pellet was re-suspended in $1 \mathrm{ml}$ of Dulbecco's Modified Eagle's Medium (DMEM) medium. Red blood cells were lysed with lysis buffer $(0.01 \mathrm{M}$ $\mathrm{KHCO}^{-}$and $0.15 \mathrm{M} \mathrm{NH} 4 \mathrm{Cl}$ ) for $40 \mathrm{~s}$ then $9 \mathrm{ml}$ of medium was added and re-centrifuged. Supernatant was discarded again and the pellet was re-suspended in DMEM medium with 10\% FBS. Cells were plated in 96 well plates at 20 cells/well and treated with $(0$ and 100) $\mu \mathrm{M}$ of Radix Pulsatillae ethanol extracts. After $24 \mathrm{~h}$ incubation, cells were stained with $0.4 \%$ trypan blue, observed and photographed under microscopy (Al Shawi, et.al., 2011).

\section{Hoechst 33258 staining to detect apoptosis}

A549 lung cancer cells from exponentially growing cultures were harvested in $1 \times 104$ cells per well in 96-well plates. A549 cells were untreated or treated with (0 and 100) $\mu \mathrm{M}$ of Radix Pulsatillae ethanol extract for $24 \mathrm{~h}$ at $37^{\circ} \mathrm{C}$. The cells were then washed in ice-cold PBS and fixed in a solution of $3.7 \%$ paraformaldehyde for $15 \mathrm{~min}$ at room temperature. To identify the apoptotic A549 cells, they were stained with Hoechst $33258(5 \mu \mathrm{g} / \mathrm{mL}$ in PBS) for $10 \mathrm{~min}$ at room temperature. The nuclei structure of the cells was examined by optical microscope with 1000 magnification (Lee, et.al., 2012; Zhang, 2000).

\section{Results and Discussion}

The previous studies of Radix pulsatillae constituents showed cytotoxic activity against pancreatic, leukemia cancers (Son, et. al. 2013; Li, et. al. 2013). In this study we identified several effective fractions which are (E2-E11), (F2-F4), and (F9-F11) through screening of Radix Pulsatillae ethanol extract fractions by using high throughput screening HTS with anti-lung activity and could use these fractions to identify the new small natural molecules which is responsible for the cancer activity as showing in table (1), the cells were treated with $0,100 \mu \mathrm{M}$ of Radix Pulsatillae ethanol extract fractions and showed clearly a strong high toxicity against A549 human lung cancer cells with low toxicity on normal splenocytes cells, perhaps due to the natural compounds mixture such as steroids, flavonoids, tannins, saponins, and carbohydrates (Mimaki, et. al. 2001; Goyal and Kumar, 2011) in Radix Pulsatillae ethanol extract which enhances the activity against lung cells, as showing in figure (1 and 2 ) and the small molecule in Radix Pulsatillae ethanol extract fractions which is responsible for anti-lung activity is still unknown and require further investigations by using HTS to identify it. Hoechst 33258 staining is a fluorescent stains for labeling DNA in fluorescence microscopy or flow cytometry, because these fluorescent stains label DNA, they are commonly used to visualize nuclei and mitochondria, because the Hoechst stains bind to DNA, they can disrupt DNA replication during cell division (apoptosis)(Elmore,2007). Consequently they are potentially mutagenic and carcinogenic so the cares are should be taken in their handling and disposal (Syed, et.al., 2013), and we used Hoechst 33258 staining to observe apoptosis affected by Radix Pulsatillae ethanol extract, the results showed an affective detection of apoptosis and could be supporting by flow cytometry analysis to determine apoptosis and necrosis cells ratio in the further studies as showing in figure 3. In conclusion, the results in vitro suggested that Chinese herb Radix Pulsatillae ethanol extracts have new small bioactive natural compounds with anti-lung cancer against A549 lung cancer cells and use the natural molecules for further cancer mechanistic researches. 
Table 1: shows high throughput screening HTS procedure to detect different toxicity fractions of Radix Pulsatillae ethanol extract (negative control is untreated cells and positive control is cells treated with DMSO) $(+=$ low toxicity; $++=$ medium toxicity; $+++=$ high toxicity) against A549 lung cancer cells. (CS means cells suspension, cells growth to 70-80\% and then digestion by trypsin and dilute it by DMEM+FBS to be single cells free of DMSO and herb extract as negative control); (A, B, C, ....H are lines mark for each well in the left side of 96 well/ plate to identify the fractions as A1, A2, A3, B1, B2,B3,

$$
\mathrm{C} 1, \mathrm{C} 2, \mathrm{C} 3, \ldots . . \mathrm{H} 1, \mathrm{H} 2, \mathrm{H} 3)
$$

Negative Radix Pulsatillae ethanol extracts control fractions

Positive control

\begin{tabular}{|c|c|c|c|c|c|c|c|c|c|c|c|c|}
\hline A & \begin{tabular}{|l|}
1 \\
$\mathrm{CS}$ \\
\end{tabular} & 2 & $\overline{3}$ & 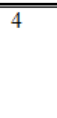 & $\overline{55}$ & $\overline{\overline{6}}$ & 7 & $\overline{88}$ & $\overline{9}$ & $\overline{10}$ & $\overline{11}$ & $\begin{array}{l}12 \\
\text { DMSO+CS }\end{array}$ \\
\hline B & CS & & & & & & & & & & & $\mathrm{DMSO}+\mathrm{CS}$ \\
\hline $\mathrm{C}$ & $\mathrm{CS}$ & & & & & & & & & & & $\mathrm{DMSO}+\mathrm{CS}$ \\
\hline D & CS & & & & & & & & & & & $\mathrm{DMSO}+\mathrm{CS}$ \\
\hline $\bar{E}$ & $\mathrm{CS}$ & $\begin{array}{l}\text { E2 } \\
+++\end{array}$ & $\begin{array}{l}\text { E3 } \\
+++\end{array}$ & $\begin{array}{l}\text { E4 } \\
+++\end{array}$ & $\begin{array}{l}\text { E5 } \\
+++\end{array}$ & $\begin{array}{l}\text { E6 } \\
+++\end{array}$ & $\begin{array}{l}\text { E7 } \\
+++\end{array}$ & $\begin{array}{l}\text { E8 } \\
+++\end{array}$ & $\begin{array}{l}\text { E9 } \\
+++\end{array}$ & $\begin{array}{l}\text { E10 } \\
+++\end{array}$ & $\begin{array}{l}\text { Ell } \\
+++\end{array}$ & $\mathrm{DMSO}+\mathrm{CS}$ \\
\hline F & $\mathrm{CS}$ & $\begin{array}{l}\text { F2 } \\
+++\end{array}$ & & $\begin{array}{l}\mathbf{F} 4 \\
+++\end{array}$ & & & & & $\begin{array}{l}\text { F9 } \\
+++\end{array}$ & $\begin{array}{l}\text { F10 } \\
++\end{array}$ & $\begin{array}{l}\text { Fll } \\
+++\end{array}$ & $\mathrm{DMSO}+\mathrm{CS}$ \\
\hline G & $\mathrm{CS}$ & & & & & & & & & & & $\mathrm{DMSO}+\mathrm{CS}$ \\
\hline H & $\mathrm{CS}$ & & & & & & & & & & & $\mathrm{DMSO}+\mathrm{CS}$ \\
\hline
\end{tabular}

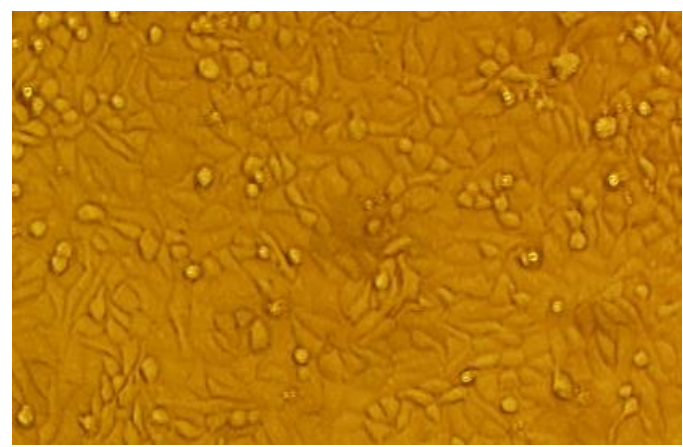

Control (0) $\mu \mathrm{M}$

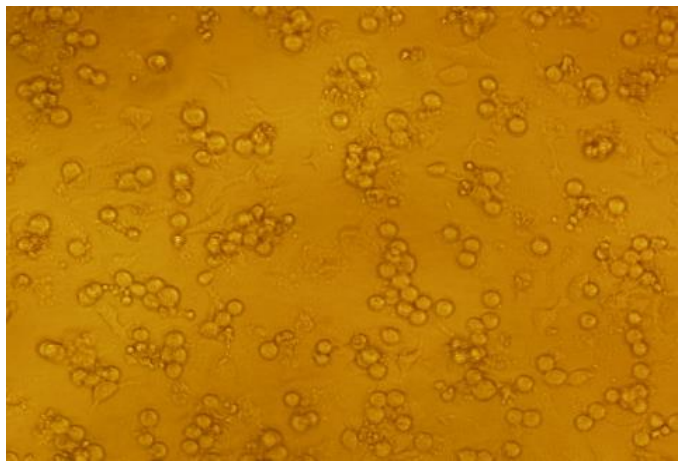

Fraction E5 (100) $\mu \mathrm{M}$

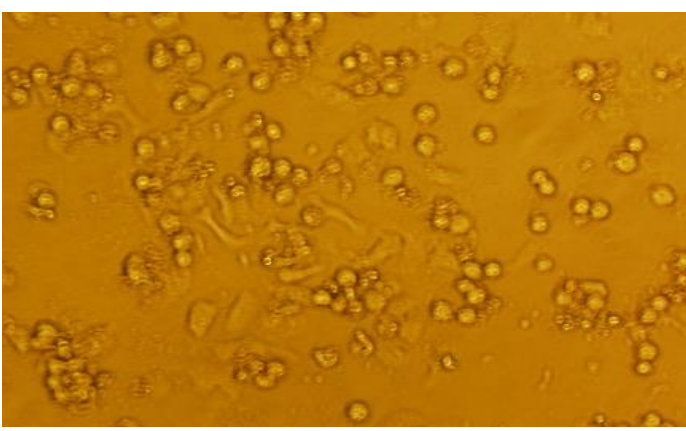

Fraction F3 (100) $\mu \mathrm{M}$

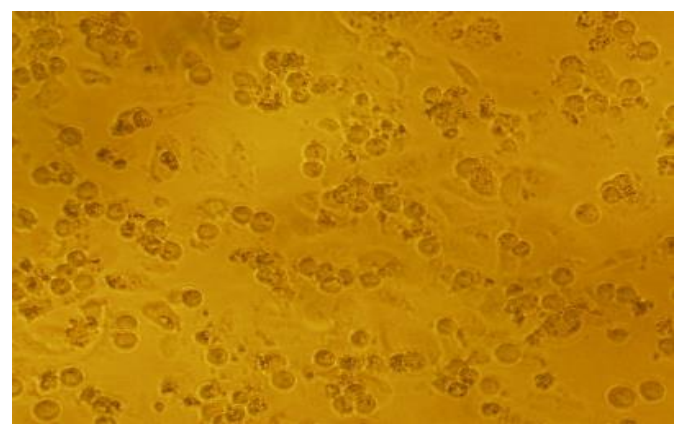

Fraction E3 (100) $\mu \mathrm{M}$

Figure 1. Morphology changes of A549 lung cancer cells; Cells were treated with (0 and 100) $\mu \mathrm{M}$ of Radix Pulsatillae ethanol extracts fractions

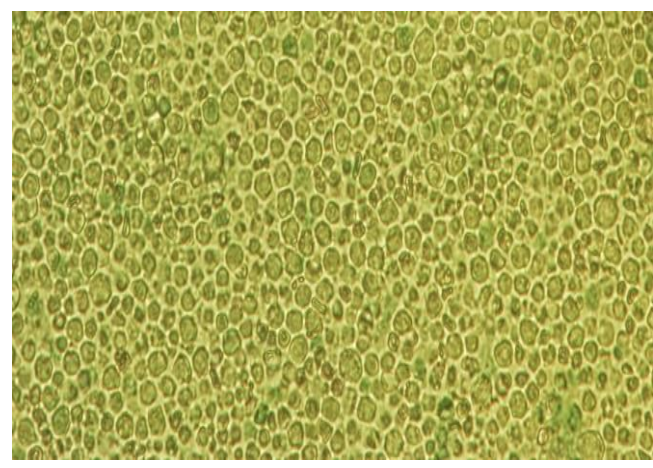

Control (0) $\mu \mathrm{M}$ 


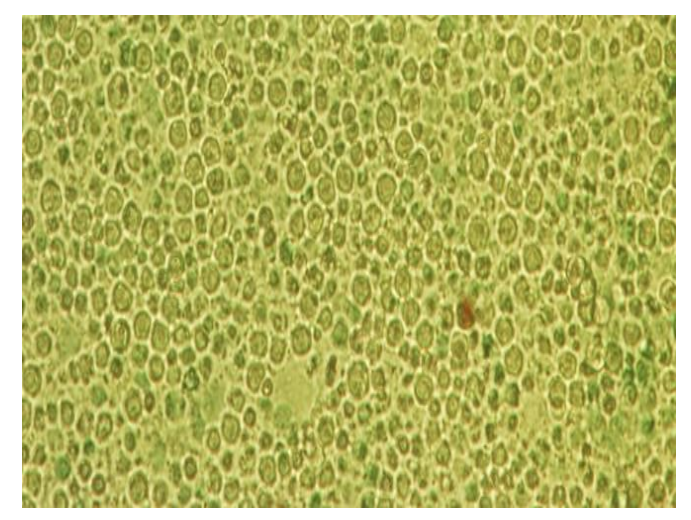

Treated with fraction E5-(100) $\mu \mathrm{M}$

Figure 2. Normal fresh mouse splenocytes treated with (0 and 100) $\mu \mathrm{M}$ of Radix Pulsatillae ethanol extracts fraction E5

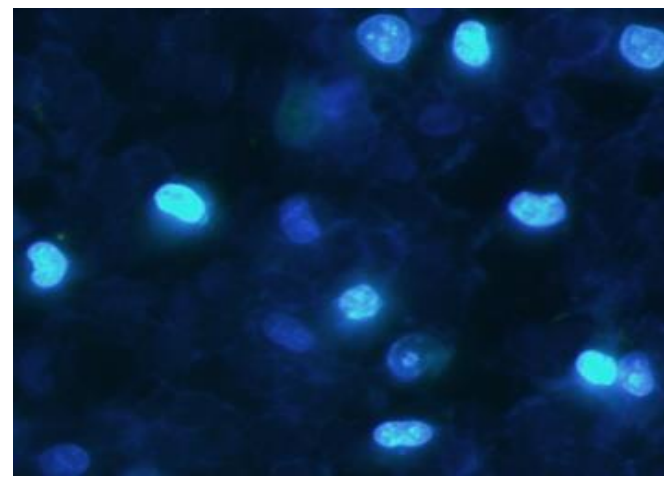

Control (0) $\mu \mathrm{M}$

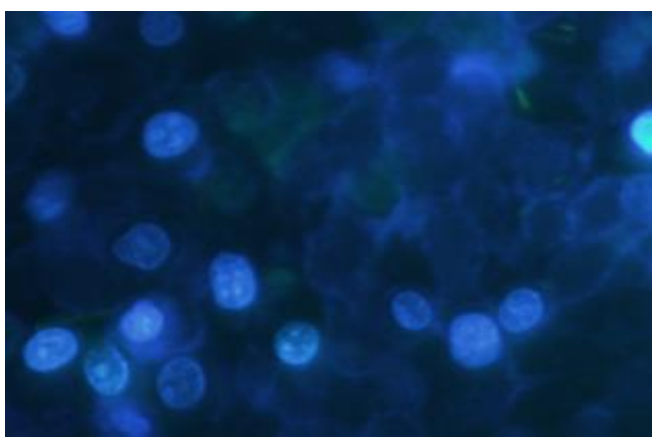

Treated with E5- (100) $\mu \mathrm{M}$

Figure 3. Hoechst 33258 staining to detect apoptosis of A549 lung cancer cells after 24h of Radix Pulsatillae ethanol extract fraction E5 treated with $(0$ and 100) $\mu \mathrm{M}$

\section{Acknowledgments}

The author is grateful to Northeast Normal University, institute of genetics and cytology, Membrane Channel Research Laboratory, Changchun city, Jilin province, China, for providing the materials, molecular techniques, and technical supports.

\section{References}

- Al Shawi, A.; Rasul, A.; Khan, M.; Iqbal, F.; Tonghui, M. (2011). Eupatilin: A flavonoid compound isolated from theartemisia plant, induces apoptosis and $\mathrm{G} 2 / \mathrm{M}$ phase cell cycle arrest in human melanoma A375 cells. Afri.

J. Phar.\&Pharm., 5(5), 582-588.

- Azim, H.A.; Ganti, A.K. (2007). Treatment options for relapsed small- cell lung cancer. Antican. dru., 18 (3), 255-261.

- Cannell, R.J.P. (1998). Natural product isolation, Humana Press, New Jersey, U.K

- Du, A.; Hu, S. (2004). Effects of a herbal complex against Eimeria tenella infection in chickens. J. Vet. Med., 51(4),194-7.

- Elmore, S. (2007). Apoptosis: A Review of Programmed Cell Death. Toxic. Patho. J. 35: 495- 516.

- Freshney, R.I. (2001). Application of cell culture to toxicology. Cell Bio. and Toxic., 17: 213-230.

- Goyal, S. and Kumar, S. (2011). Pharmacognostic Standardization of Pulsatilla nigricans Stoerck. Inter. J. Pharma. Sci. \&Drug Res. 3(2): 158161.

- Guo, X. Z.; Song, C.L.; Zhang, C.D. (2002). The regular of herbal application for lung cancer. Liao. J. Tradi. Chin. Med., 29: 273.

- Habib, O.; Al-Diab, J.; Mohsin, A.; Al- Elwe W.; Hasan J.; Al-Haroon S.; Al- Emara K. (2010). Experience and outcome of population- based cancer registration in Basra Southern Iraq in 2005- 2008. APJCP, 11(4), 1151-4.

- He, H.H.; Shen, H.; Zheng, K. (2012). Observation of the curative effect of qingchang huashi recipe for treating active ulcerative colitis of inner- accumulation of damp- hea syndrome. Zhongguo Zhong Xi Yi Jie $\mathrm{He} \mathrm{Za}$ Zhi., 32(12),1598-601[Article in Chinese].

- Horn, L.; Pao, W.; Johnson, D.H. (2012). "Harrison's Principles of Internal Medicine". Chapter 89. 18th ed. McGraw-Hill. ISBN 0-07174889-X. 
- Khan, M.; Yu, B.; Rasul, A.; Al Shawi, A.; Yi, F.; Yang, H.; Tonghui, $\quad$ M. (2012) .Jaceosidin Induces Apoptosis in U87 Glioblastoma Cells through G2/M Phase Arrest. Evide.-Base Comple. \&Altern. Med., Volume 2012, Article ID 703034, 12 pages.

- Lee, D.H.; Park, K.I.; Park, H.S.; Kang, S.; Nagappan, A.; Kim, J.; Kim, E.; Lee, W.; Hah, Y.; Chung, H.; An, S.; Kim, G. (2012) Flavonoids Isolated from Korea Citru aurantium L. Induce G2/M Phase Arrest and Apoptosis in Human Gastric Cancer AGS Cells. EvidBased Compl. Alter. Med. 2012 ;515901.

- American Cancer Society (2014). Lung Cancer. Atlanta, Ga: American Cancer Society; 2014.

- Murray, N.; Turrisi, A.T. (2006). A review of first-line treatment for small-cell lung cancer. J. Thora. Onc., 1 (3), 270-278.

- Li, W.; Ding, Y.; Sun, N.; Yan, T.; Yang, Y.; Choi, W.; Kim, J.; Kang, K.; Kim, H. (2013). Oleanane-type triterpenoid saponins from the roots of Pulsatilla koreanaandtheir apoptosisinducing effects on HL-60 human promyelocytic leukemia cells. Arch. Pharm. Res. 36(6):768-74.

- Liu, L.F.; Liang, C.H.; Shiu, L.Y.; Lin, C.; Kuo, K. (2004). Action of solamargine on human lung cancer cells enhancement of the susceptibility of cancer cells to TNFs. FEBS Lett., 577(1-2), 67-74

- MacCallum, C.; Gillenwater, H.H. (2006). Secondline treatment of small-cell lung cancer. Curr. Onc. Rep., 8 (4), 258-264.

-Mimaki, Y.; Yokosuka, A.; Kuroda, M.; Hamanaka,M.; Sakuma, C.; Sashida, Y. (2001). New bisdesmosidic triterpene saponins fromthe roots of Pulsatilla chinensis.J Nat.Prod. 64(9):1226-9.

- McNabola, A.; Gill, L.W. (2009). The control of environmental tobacco smoke: a policy review. Intern. J. Enviro. Res. \&Pub.Hea., 6 (2), 741- 758.

- Rahim, H.F.; Sibai, A.; Khader, Y.; Hwalla, N.; Fadhil, I.; Alsiyabi, H.; Mataria, A.; Mendis, S.; Mokdad, A.H.; Husseini, A. (2014). Noncommunicable diseases in the Arab world. Lancet., 383(9914), 356-67.

- Rasul A.; Yu B.; Khan M.; Zhou K.; Iqbal F.; Tonghui, M.; Yong H. (2012). Magnolol, natural compound, induces apoptosis of SGC-

7901 human gastric adenocarcinoma cells via the mitochondrial and PI3K/Akt signaling pathways. Inter. J. Onco. 40: 1153-1161.

- Son, K.; Jung, H.; Lee, S.; Lee, H.; Kim, J.; Yan, H.; Ryu, L.; Hong, S. (2013). SB365, Pulsatilla saponinDsuppresses proliferation and induces apoptosis of pancreatic cancer cells. Oncol Rep. 30(2):8018.

- Syed, N.; Abdul Wahab, N.; Abd Malek, N. (2013). In Vitro Morphological Assessment of Apoptosis Induced by Antiproliferative Constituents from the Rhizomes of Curcuma zedoaria. Evid-Based Compl. Alter. Med. 2013:257108.

- Zhang J. and Xu M. (2000). DNA fragmentation in apoptosis. Cell Res., 10: 205 -211.

- Zhou, Y.; Gao, W.; Li, K. (2008) .Chinese herbal medicine in the treatment of lung cancer. Review, Asi. J. Tradi. Med., 3 (1): 1-11. 